\title{
KESEHATAN MENTAL MAHASISWA DITINJAU DARI RELIGIUSITAS DAN KEBERMAKNAAN HIDUP
}

\author{
Baldi Bukhorl \\ Institut Agama islam Negeri Wallsongo Semarang
}

\begin{abstract}
This research aimed to investigate correlation among religiousity, iffe meaning and student's mental health. Hypotheses proposed there's positive comrlation among those variables. Subjects were 127 students of Da'wah Faculty of IAIN Walisongo and assigned proportional random sampling technique.

Three scales were used to collect data, among those were religiousity scare, lifemeaning scale and mental helath scale. Multiple regression was used b test the hypotheses. This research found that there's positive correlation among religiousity, life-meaning and students mental helath. religiouslty, lif $3-$-meaning donate $57,2 \%$ for students mental helath.
\end{abstract}

Keywords: Religiousity, ife meaning, and mental health

\section{Pengantar}

Kehidupan manusia d zaman dulu maupun kini diharapkan dinaungi suasana yang positif. Kesehatan mental merupakan salah satu hal yang selalu didambakan manusia. Kesehatan mental oleh para ahli didefinisikan sebagai terwujudnya keharmonisan yang sungguh-sungguh antar fungsi-fungsi jiwa serta mempunyai kesanggupan untuk menghadapi problemproblem biasa yang terjadi dan merasakan secara positif kebahagiaan dan kemampuan dirinya (Daradjat, 2001). Yang menjadi permasalahan adalah dalam kehidupan kekinian, masihkan hai-hal di atas selalu berlangsung?

Modernisasi, industrialisasi, dan kemajuan ilmu pengetahuan-teknologi (iptek) telah menciptakan peradaban yang menjanjikan kemajuan dan kemudahan bagi pemenuhan kebutuhan manusla. Namun di balik itu, hal-hal di atas mengakibatkan beban psikologis dalam kehidupan pribad, keluarga, dan masyarakat semakin meningkat, sehingga kegelisahan seakanakan melanda masyarakat modern balk di kota maupun desa. Kehidupan modern yang materialistik cenderung menuntut pola pandang serba rasional, kerja efisien efektif, dan kesibukan mencari nafkah, sehingga mengabaikan hal-hal yang mengandung kebermaknaan hidup, seperti kekhusukan ibadah, kebersamaan hidup, kepasrahan diri, kesabaran, istiqomah, dan sikap-sikap etik religius lainnya (Bastaman, 1996).

Modernisasl juga menimbulkan perubahan-perubahan sosial yang sangat cepat sehingga tidak semua orang mampu menyesuaikan diri dengan perubahanperubahan tersebut sehingga dapat menlmbulkan kebingungan, kecemasan, ketakutan, dan frustrasi. Frustrasi dan ketakutan-ketakutan tersebut menimbulkan ketegangan-ketegangan batin, konflikkonflik batin, dan gangguan-gangguan emosional, yang menjadi persemaian subur bagi timbuinya ketidaksehatan mental (Kartono dan Andari, 1989).

Ketidaksehatan mental seseorang akan semakin sulit dihindari bila seseorang tidak memliki daya tahan mental dan spirttual yang tangguh. Salah satu hal yang dapat meningkatkan daya tahan seseorang dari ketidaksehatan mental adalah agama. Agama mempunyal peranan penting dalam pembinaan moral karena nillai-nilai moral yang datang dari agama bersifat tetap dan 
universal. Apabila seseorang dihadapkan pada suatu dilema, ia akan menggunakan pertimbangan-pertimbangan berdasarkan nilai-nilai moral yang datang dari agama. Di manapun orang itu berada dan pada posisi apapun, akan tetap memegang prinsip moral yang telah tertanam dalam hati nuraninya (Daradjat,1993). Sejalan dengan pendapat tersebut, Kartono dan Andari (1989) menyatakan bahwa agama berperan besar dalam mengatasi mental yang sakit. Hal tersebut dapat dilihat pada seseorang yang memiliki keimanan yang teguh dan mantap. Dengan keimanan yang teguh dan mantap, dalam diri individu telah tertanam keyakinan yang kuat, bahwa tiada Tuhan selain Allah yang menjamin dan memberikan ketenteraman dalam jiwa manusia, sehingga hilanglah rasa takut dan gelisah serta penyakit mental lainnya. Dengan kata lain, a pabila seseorang telah mengintemalisasikan nilai-nilai agama yang dianutnya maka dapat diasumsikan akan memperoleh kesehatan mental.

\section{Dasar Toori}

Bagian inl akan menerangkan tentang kesehatan mental, religiusitas, kebermaknaan hidup, hubungan antara religiusitas dan kesehatan mental, serta hubungan kebermaknaan hidup dan kesehatan mental.

\section{Kesehatan Mental}

Untuk mengetahui apakah seseorang terganggu mentalnya atau tidak bukanlah hal yang mudah, sebab tidak mudah diukur, diperiksa ataupun dideteksi dengan alat-alat ukur seperti halnya dengan kesehatan jasmani/badan (Daradjat, 2001). Bisa dikatakan bahwa kesehatan mental adalah relatif, dalam arti tidak terdapat batas-batas yang tegas antara wajar dan menyimpang. Akibatnya, tidak ada batas yang tegas antara kesehatan mental dengan gangguan kejiwaan. Keharmonisan yang sempuma di dalam jwa tidak ada, yang diketahul adalah seberapa jauh kondisi seseorang dari kesehatan mental yang normal. Meskipun demikian ada beberapa ahli yang berusaha merumuskan tolok ukur kesehatan mental seseorang. Hal tersebut terlihat dari pengertian kesehatan mental yang mereka ungkapkan.

Daradjat (2001) menyatakan bahwa ada banyak definisi tentang kesehatan mental yang diberikan para ahll, sesuai dengan pandangan dan bidangnya masingmasing. Definisi tersebut antara lain: 1). Kesehatan mental adalah terhindarnya orang dari gejala-gejala gangguan jwa (neurose) dan dari gejala gejala penyakit jiwa (psychose), 2). Kesehatan mental adalah kemampuan untuk menyesuaikan diri dengan diri sendiri, dengan orang lain dan masyarakat serta lingkungan di mana ia hidup. 3). Kesehatan mental adalah pengetahuan dan perbuatan yang bertujuan untuk mengembangkan dan memanfaatkan segala potensi, bakat dan pembawaan yang ada semaksimal mungkin, sehingga membawa kepada kebahagiaan diri dan orang lain; serta terhindardari gangguan dan penyakit jwa. 4). Kesehatan mental adalah terwujudnya keharmonisan yang sungguhsungguh antara fungsi-fungsi jiwa, serta mempunyai kesanggupan untuk menghadapi problem-problem biasa yang terjadi, dan merasakan secara positif kebahagiaan dan kemampuan dirinya.

Sadil (Bastaman, 1995) mengemukakan tiga orientasi dalam kesehatan jiwa, yakni: 1).Orientasi Klasik. Seseorang dianggap sehat bila ia tak mempunyai keluhan tertentu, seperti: Ketegangan, rasa lelah, cemas, rendah diri atau perasaan tak berguna, yang semuanya menimbulkan perasaan "sakit" atau "rasa tak sehat" serta mengganggu efisiensi keglatan sehari-hari. 2). Orientasi penyesuaian diri. Seseorang dianggap sehat secara psikologis bila ia mampu mengembangkan dirinya sesuai dengan tuntutan orang-orang lain serta lingkungan sekitamya. 3). Orientasi pengembangan potensi: Seseorang dianggap mencapai taraf kesehatan jiwa, bila ia mendapat kesempatan untuk mengembangkan potenslalitasnya menuju kedewasaan sehingga bisa dihargai oleh orang lain dan dirinya sendiri.

Atas dasar pengertian kesehatan 
mental yang diberikan oleh kedua ahli terse but dapat diajukan tolok ukur kesehatan mental atau kondisi mental yang sehat, yaitu:

a. Bebas dari gangguan dan penyakitpenyakit kejwaan.

b. Mampu secara luwes menyesuaikan diri dan menciptakan hubungan an tar pribadi yang bermanfaat dan menyenangkan.

c. Mengembangkan potensi-potensi pribadi (bakat, kemampuan, sikap, sifat, dan sebagainya) yang baik dan bermanfaat bagi diri sendiri dan lingkungan.

\section{Religiusitas}

Menurut Jalaluddin (2000), religlusitas dapat didefinisikan sebagai suafu keadaan yang ada dalam diri individu yang mendorongnya untuk bertingkah laku sesuai dengan kadar ketaatannya terhadap agama. Widjanarko (1997) berpendapat bahwa religiusitas dapat diartikan sebagal keadaan yang ada di dalam diri manusia dalam merasakan dan mengakui adanya kekuasan tertinggi yang menaungi kehidupan manusia dengan cara melaksanakan semua perintah Tuhan sesual dengan kemampuannya dan menlnggaikan semua larangan-Nya, sehingga hal ini akan membawa ketenteraman dan ketenangan pada dirinya.

Dari beberapa definisi tersebut dapat diambil kesimpulan bahwa religiusitas dapat diartikan sebagai suatu keadaan yang ada dl dalam diri seseorang yang mendorongnya bertingkah laku, bersikap, dan bertindak sesuai dengan ajaran agamanya.

Religiusitas dapat dibagi menjadi beberapa dimensi. Pembagian yang paling rinci sebagaimana dikemukakan oleh Glock dan Stark (Robertson, 1988; Ancok dan Suroso, 2000). Keduanya berpendapat bahwa ada lima dimensi religiusitas, yakni: dimensi ideologis/keyakinan, ritualistik/ praktik, eksperiensial/pengalaman, intelektual/pengelahuan, dan konsekuensiai. Pertama, Dimensi ideologis/keyakinan berkenaan dengan seberapa tingkat keyakinan seseorang terhadap kebenaran ajaran agamanya, terutama terhadap ajaranajaran yang fundamental atau bersifat dogmatis. Dalam Islam. isi dari dimens! keyakinan adalah menyangkut keyakinan tentang adanya Allah, Malaikat, Rasul/Nabi, kitab Allah, surga, neraka, qodho dan qodar (Ancok dan Suroso, 2000).

Kedua, Dimensi ritualistik/praktik berkenaan dengan seberapa tingkat kepatuhan seseorang dalam mengerjakan kegiatan-kegiatan ritual sebagaimana diperintahkan atau dianjurkan oleh agama yang dianutnya. Dalam Is|am, Isi dimensi ritualistik/praktik meliputi kegiatan-kegiatan antara lain seperti pelaksanaan shalat, puasa, zakat, haji bila mampu, pembacaan Al Quran, pemanjatan doa, dan lain sebagainya (Ançok dan Suroso, 2000).

Ketiga, Dimensi eksperiensial/ pengalaman berkenaan dengan seberapa tingkat seseorang dalam merasakan dan mengalami perasaan-perasaan dan pengalaman religius. Dalam islam, isi dimensi eksperiensial/pengalaman meliputi perasaan dekat dengan Allah, dicintai Allah, doa-doa sering dikabulkan, perasaan tenteram dan bahagia karena menuhankan Allah, bertawakal, dan bersyukur kepada Allah, dan sebagainya (Ancok dan Suroso, 2000).

Keempat, Dimensi intelektual/ pengetahuan berkenaan dengan seberapa tingkat pengetahuan dan pemahaman seseorang terhadap ajaran agamanya, terutama mengenai ajaran pokok agamanya sebagaimana termuat daiam kitab sucinya. Dalam Islam, isi dimensi inteloktual/ pengetahuan meliputi pengetahuan tentang isi Al-Quran, pokok-pokok ajaran yang harus dilmanl dan dilaksanakan, hukum Islam, sejarah Islam, dan sebagainya (Ancok dan Suroso, 2000).

Kelima, Dimensi pengamalan/ konsekuensi berkenaan dengan seberapa tingkat seseorang dalam berperilaku yang dimotivasi oleh ajaran agamanya. Perilaku yang dimaksud adalah perilaku duniawi, yakni bagaimana individu berhubungan dengan dunianya. Dalam Islam, isi dimensi pengamalan/konsekuensi meliputi perilaku suka menolong, berderma, menegakkan kebenaran dan keadilan, berlaku jujur, memaafkan, menjaga amanat, menjaga lingkungan, tidak mencuri, tidak berjudi, tidak 
menipu, mematuhi norma-norma Islam dalam berperilaku seksual, berjuang untuk hidup sukses menџrut ukuran Islam, dan sebagainya (Ancok dan Stroso, 2000).

\section{Kebermaknaan Hidup}

Frankl (2003) berpendapat bahwa kebermaknaan hidup adalah keadaan yang menunjukkan sejauhmana seseorang telah mengalami dan menghayati kepentingan keberadaan hidupnya menurut sudut pandang dirinya sendiri. Anggriany (2006) mendeflnisikan kebermaknaan hidup sebagai penghayatan seseorang mengenal kualitas, tujuan, dan harapan dalam hidupnya agar dapat berarti bagi diri sendiri dan sesamanya.

MenurutAncok (2003) kehldupan yang bermakna akan dimiliki seseorang apabila dia mengetahui makna dari pilihan hidupnya. Makna hidup adalah hal-hal yang memberikan arti khusus bagl seseorang, yang apabila berhasil dipenuhi akan menyebabkan kehidupannya dirasakan berarti dan berharga, sehingga akan menimbulkan penghayatan bahagia (happiness) (Budiharjo, 1997). Leblh lanjut Ancok (2003) menyatakan bahwa makna hidup ini bermula darl adanya visi kehidup an, harapan dalam hidup, dan adanya alasan kenapa seseorang harus terus hidup. Dengan adanya visi kehidupan dan harapan hidup itu seseorang akan tangguh di dalam menghadapi kesulitan hidup sebesar apapแn. Kebermaknaan ini adalah sebuah kekuatan hidup manusla, yang selalu mendorong seseorang untuk memiliki sebuah komitmen kehidupan.

Kebermaknaan hidup dalam kehidupan manusia sebagai tujuan hidup yang harus diperjuangkan dengan sungguhsungguh. Madjid (Bastaman, 1996) menyatakan:

"Prinsip bahwa hidup ini bermakna menjadikan hidup penuh keoptimisan karena hidup ini cukup berharga untuk dijaiani dengan penuh minat dan kesungguhan. Hal ini karena iujuan hidup adalah memperoleh kebahagian dan kebermaknaan hidup ada dalam usaha mencapai tujuan itu. Kebahagian setiap orang merupakan tujuan yang cukup berharga untuk diperjuangkan agar terwujud bahkan kalau perlu dengan pengorbanan. Maka hidup ini cukup berharga dan kenyataannya jalah bahwa hampir setiap orang berjuang untuk mempertahankan dan meningkat taraf hidupnya biar pun ia mungkin merasa sengsara di dunia. Namun adanya harapan dalam hati menjadi penyangga kekuatan jiwanya untuk tetap hidup kalau dapat selama mungkin".

Berdasarkan beberapa pendapat df atas dapat simpulkan bahwa kebermaknaan hldup adalah kuralitas penghayatan individu terhadap keberadaan dirinya, yang memuat hal-hal yang dianggap penting, dirasakan berharga, diyaklnl sebagal sesuatu yang dianggap benar dan dapat memberikan arti khusus yang menjadi tujuan hid up seseorang dan apabila berhasil ditemukan dan dipenuhi akan menyebabkan hidup berarti dan berharga bagi diri sendiri dan sesama serta menimbulkan kebahaglaan.

Karakteristik makna hidup adalah personal, temporer, dan unik, artinya apa yang dlanggap penting dapat berubah dari waktu ke waktu. Saat-saat bermakna berarti bagi seseorang belum tentu berartl pula bagi orang lain. Sifat lainnya adalah kongkrit dan spesifik, yakni makna hidup benar-benar dapat ditemukan dalam pengalaman nyata dan kehidupan sehari-hari, serta tak harus selalı dikaitkan dengan hal-hal serba abstrak, filosofis, dan Idealistis, atau karya seni dan prestasl akademis yang serba menakjubkan. Makna hidup pun berfungsi sebagai pedoman dan arah dari keglatan seseorang, sehingga seakan-akan menantang seseorang untuk memenuhlnya (Bastaman, 1995).

Mengingat keunikan dan kekhususannya itu, maka makna hidup hanya bisa dipenuhi oleh yang bersangkutan; hanya dengan cara itulah ia bisa memiliki arti yang bisa memuaskan keinginan orang tersebut untuk mencari makna hldup (Frankl, 2003). Dengan kata lain, makna hidup tidak dapat diberikan oleh 
siapapun, tetapi harus dicari dan ditemukan sendiri. Orang lain hanyalah sekedar menunjukkan berbagai sumber kebermaknaan hidup dan hal-hal yang mungkin berarti. Tetapi pada akhirnya terpulang pada orang yang ditunjuki untuk menentukan sendiri apa yang dianggap dan dirasakan bermakna baginya (Bastaman, 1995).

Menurut Frankl (2003), ada tiga komponen kebermaknaan hidup, yakni 1). kebebasan berkehendak, 2). kehendak hidup bermakna, 3). makna hidup. Kebebasan berkehendak adalah kebebasan yang dimiliki seseorang untuk menentukan pilihan di antara altematif-alternatif yang ada, dan oleh karenanya seseorang mengambil peranan yang besar dalam menentukan nasibnya sendiri. Manusia memiliki kebebasan yang luas, tetapi sifatnya terbatas, karena manusia adalah makhluk terbatas. Sekurang-kurangnya ada dua hal yang membatasi kebebasan ini, yakni: pertama, kebebasan manusia bukan merupakan kebebasan dari kondisi-kondisi (biologis, psikologis, dan sosiologis), melainkan kebebasan untuk menentukan sikap terhadap kondisi-kondisi tersebut. Kedua, kebebasan harus disertai tanggung jawab. Tampa tanggung jawab, kebebasan mudah sekali berkembang menjadi kesewenang-wenangan (Franki, 2003).

Kehendak hidup bemakna adalah hasrat yang memotivasi setiap orang untuk bekerja, berkarya, dan melakukan kegiatankegiatan penting lainnya dengan tujuan agar hidupnya berharga dan dihayati secara bermakna. Jadi sebagai motivasi utama manusia, kehendak hidup bermakna mendambakan seseorang menjadi pribadi yang penting dan berharga serta memillki tujuan hidup yang jelas dan sarat dengan kegiatan-kegiatan yang bermakna pula (Frankl, 2003).

Makna hidup adalah sesuatu yang dianggap penting, benar, dan didambakan serta memberi nilai khusus bagi seseorang. Bila berhasil ditemukan dan dipenuhi akan menyebabkan kehidupan ini dirasakan demikian berarti dan berharga (Frankl dalam Bastaman, 1996).
Menurut Crumbaugh dan Maholich (Koeswara, 1992) ciri-ciri kebermaknaan hidup yaitu: 1). tujuan hidup, 2). kepuasan hidup, 3). kebebasan memilih, 4). gairah hidup, dan 5). tanggung jawab. Mereka yang menghayati hidup bermakna dapat dlgambarkan sebagai berikut:

Mereka menjalani kehidupan seharihari dengan penuh semangat dan gairah hldup serta jauh dari perasaan hampa. Mereka juga mempunyai tujuan hldup yang jelas, baik tujuan jangka pendek maupun tujuan jangka panjang. Kegiatan-Kegiatan mereka pun menjadi terarah. Selain itu mereka juga merasakan sendiri kemajuankemajuan yang telah mereka capai. Tugastugas dan pekerjaan sehari-hari bagi mereka merupakan sumber kepuasan dan kesenangan tersendiri sehingga mereka mengerjakannya dengan bersemangat dan bertanggung jawab. Hari demi hari mereka menemukan beraneka ragam pengalaman baru dan hal-hal menarik yang semuanya menambah pengalaman hidup mereka. Mereka mampu menyesuaikan diri dengan tingkungan, dalam arti menyadari batasanbatasan lingkungan, tetapi dalam batasanbatasan itu mereka dapat menentukan sendiri apa yang paling baik untuk mereka lakukan. Mereka juga menyadari bahwa makna hidup dapat ditemukan dalam kehidupan, betapapun buruknya keadaan. Kalaupun mereka pada suatu saat mengalami penderitaan, mereka akan menghadapinya dengan sikap tabah. Mereka sadar bahwa senantiasa ada makna dan hikmah of balik penderitaannya itu. Mereka benar-benar menghargai hidup dan kehidupan, karena mereka menyadari bahwa hidup dan kehidupan ku senantiasa menawarkan makna yang harus mereka penuhi. Mereka menganggap bahwa usaha memenuhi makna hidup itu secara bertanggung jawab merupakan tantangan. Mereka juga mampu menclntai dan menerima cinta kasih orang lain, serta menyadari bahwa cinta kasth merupakan salah satu hal yang menjadikan hidup ini indah. Mereka adalah orang-orang yang benar-benar menghayati bahwa hidup dan kehidupan mereka bermakna (Bastaman, 1996). 


\section{Hubungan religiusitas dengan kesehatan mental}

Kesehatan mental ditentukan oleh beberapa kondisi yang mempengaruhinya, salah satunya adalah kondisi keberagamaan seseorang (Surya dalam Akhmad, 2005). Sejalan dengan pendapat tesebut, Daradjat (1993) menyatakan bahwa agama dengan ketentuan dan hukum-hukumnya telah dapat membendung terjadinya gangguan kejiwaan, yaitu dengan dihindarkannya segala kemungkinan sikap, perasaan, dan kelakuan yang membawa pada kegelisahan. Penelitian Bergin (1987) menemukan bahwa orientasi religius intrinsik diasosiasikan dengan bebas dari keragu-raguan, minimasi kecemasan, kegigihan berusaha, dan kesiapsiagaan.

Orang yang beragama, kesukaran atau bahaya sebesar apapun yang harus dihadaplnya, akan sabar, karena dia merasa bahwa kesukaran dalam hidup itu merupakan bagian dari cobaan Allah Kepada hamba-Nya yang beriman. la tidak memandang setiap kesukaran atau ancaman terhadap dirinya dengan cara negatif, akan tetapi sebaliknya melihat bahwa di celah-celah kesukaran tersebut terdapat harapan-harapan. Dia tidak akan menyalahkan orang lain atau mencari sebabsebab negatif pada orang lain (Daradjat, 1993).

Pelaksanaan agama dalam kehidupan sehari-hari juga dapat membentengi orang dari kejatuhan kepada gangguan jwa dan dapat pula mengembalikan kesehatan jwa bagi orang yang gelisah (Daradjat, 1993). Karena kegelisahan-Kegelisahan dan kecemasan-Kecemasan yang tidak berujung pangkal itu, umumnya datang dari ketidakpuasan atau kekecewaankekecewaan, sedangkan agama dapat monolong orang untuk monerima kekecewaan sementara dengan jalan memohon ridho Allah dan terbayanglah kebahagiaan yang akan dirasakannya di kemudian hari. Sembahyang, doa-doa, dan permohonan ampunan kepada Allah, merupakan cara-cara pelegaan batin yang akan mengembalikan ketenangan dan
Ketenteraman jiwa kepada orang yang melakukannya. Semakin dekat seseorang kepada Tuhan, dan semakin banyak ibadahnya, maka akan semakin tenteramlah jiwanya serta semakin mampu ia menghadapi kekecewaan dan kesukarankesukaran dalam hidup, demlkian pula sebaliknya, semakin jauh orang itu dari agama akan semakin susahlah baglnya untuk mencari ketenteraman batin. Dengan demikian dapat diperoleh pemahaman bahwa agama merupakan faktor penting yang dapat membimbing seseorang dalam mendapatkan Kesehatan mental.

\section{Hubungan kebermaknaan hldup dengan kesehatan mental}

Kesehatan mental seseorang dipengaruhi oleh dua faktor, yakni faktor internal dan faktor ekstemal. Yang termasuk faktor internal antara lain: kepribadian, kondisi fisik, perkembangan dan kematangan, kondisi psikologis. Keberagamaan, sikap menghadapi problema hidup, dan keseimbangan dalam berfikir. Adapun yang termasuk faktor eksternal antara lain: keadaan ekonomi, budaya, dan kondisi lingkungan, baik IIngkungan keluarga, masyarakat, maupun lingkungan pendidikan (Daradjat, 2001).

Diantara kedua faktor d atas, yang paling dominan pengaruhnya adalah faktor internal dibandingkan dengan faktor eksternal. Hal tersebut sesuai dengan pendapat Daradjat (2001), bahwa sesungguhnya Ketenangan hidup. ketenteraman jiwa atau kebahagiaan batin, tidak banyak tergantung kepada faktor-faktor luar seperti keadaan sosial, ekonomi, politik, adat keblasaan, dan sebagainya; akan tetapi lebih tergantung Kepada cara dan sikap menghadapi faktor-faktor tersebut.

Dari uraian di atas terlihat bahwa sumber utama Kesehatan mental adalah bagaimana cara dan sikap seseorang dalam menghadapi persoalan hidup yang ia hadapi. Tidak jauh berbeda dengan kesehatan mental, kebermaknaan hidup seseorang juga bersumber dari bagaimana sikapnya dalam menghadapi persoalan hidup. Menurut Bastaman (1996) salah satu sumber 
kebermaknaan hidup adalah nilai-nilai sikap. Nilal sikap merupakan sikap yang diberikan individu terhadap kondisi-kondisi tragis yang telah terjadi, seperti penyakit, penderitaan, dan kematian. Situasi-situasi yang buruk, yang menimbulkan keputusasaan dan tampak tanpa harapan dapat memberikan kesempatan yang sangat besar bagi individu dalam menemukan makna hidupnya. Dengan mengambil sikap yang tepat, maka beban pangalaman-pengalaman tragis itu dapat berkurang, bahkan dapat menimbulkan makna yang lebih berarti. Melalui dari peristiwa tersebut dapat mengallr berkah dan pelajaran berharga yang justru membantu proses kematangan dan memberi sumbangan bagi kebaikan di masa mendatang.

Dengan demikian dapat diambil pemahaman bahwa sehat atas tidaknya mental seseorang dan bermakna atau tidaknya hldup seseorang sangat tergantung pada bagaimana sikap seseorang dalam menghadapi problema kehidupan yang mereka hadapi. Jika seseorang bisa bersikap positif terhadap problema yang mereka hadapi maka kesehatan mental dan kebermaknaan hidup akan mereka dapatkan.

Keterkaitan antara kebermaknaan hidup dengan kesehatan mental juga dapat dilihat dari uraian berikut: Logoterapi yang lazim dikenal sebagai "Aliran Psikoterapi Ketiga dari Wina", memusatkan perhatiannya pada makna hidup dan upaya manusia untuk mencari makna hidup. Logoterapl percaya bahwa periuangan untuk menemukan makna dalam hidup seseorang merupakan motivator utama orang tersebut (Frankl, 2003). Lebih lanjut Frankl (2003) menyatakan bahwa upaya manusia untuk mencari makna hidup dapat menimbulkan ketegangan batln, bukan keseimbangan batin. Tetapi ketegangan seperti itu justru merupakan prasyarat yang sangat dlbutuhkan bagl tercapainya kesehatan mental. Dengan demikian dapat dikatakan bahwa terdapat keterkaitan antara logoterapi dengan kesehatan mental.

Logoterapi mengajarkan bahwa manusla harus dipandang sebagai kesatuan raga-jiwa-rohani yang tak terpisahkan. Seorang psikoterapis tidak mungkin dapat memahami dan melakukan terapi secara baik apabila mengabaikan dimensi rohani yang justru merupakan salah satu sumber kekuatan dan kesehatan manusia. Selain itu logoterapi memusatkan perh atian pada kualitas-kualitas insani, seperti hasrat untuk hidup bermakna, hati nurani, kreativitas, dan tanggung jawab. FrankI memanfaatkan dan mengaplikasikan kualitas-kualitas itu dalam terapi dan pengembangan kesehatan mental, termasuk penyembuhan mental yang sakit (Bastaman, 1996).

\section{Hipotesis}

Berdasar pada asumsi-asumsi teoretik di atas, maka hipotesis penelitian yang diajukan adalah: Ada korelasi positif yang signiflkan antara rellgiusitas dan kebermaknaan hldup dengan kesehatan mental mahasiswa.

\section{Metode Penelitian}

Populasi dalam penelitian ini adalah semua mahasiswa Fakultas Dakwah IAIN Walisongo Semarang. Teknik pengambilan sampel yang digunakan dalam penelitian ini adalah proportional random sampling, yaltu memilih individu-Indlvidu yang ada di kelaskelas perkuliahan dari tiap-tiap angkatan secara random dengan mempertimbangkan keseimbangan jumlah mahasiswa dari tiap angkatan. Berdasarkan pertimbangan tersebut diperoleh sampel sebanyak 127 orang, terdlri dari angkatan 2005 sebanyak 22 orang, angkatan 2004 sebanyak 19orang, angkatan 2003 sebanyak 23 orang, angkatan 2002 sebanyak 32 orang dan angkatan 2001 sebanyak 31 orang.

Penelitian ini menggunakan satu variabel tergantung yaknl kesehatan mental dan dua varlabel bebas, yakni religiusitas dan kebermaknaan hidup.

Kesehatan mental adalah terhindarnya seseorang dari gejala gangguan atau penyakit mental, terwujudnya keharmonisan yang sungguh-sungguh antar fungsi-fungsi jiwa serta mempunyal 
kesanggupan untuk menghadapi problemproblem biasa yang terjadi dan merasakan secara positif kebahagiaan dan kemampuan dirinya. Adanya kemampuan yang dimiliki untuk menyesuaikan diri dengan dirinya sendiri dan lingkungannya.

Pengukuran kesehatan mental dilakukan dengan menggunakan skala kesehatan mental yang disusun oleh penulis. Skala ini merupakan sintesa dari ciri-ciri kesehatan mental yang dikemukakan oleh Daradjat (2001) dan Sadli (Bastaman, 1995). Skala ini terdiri dari tiga aspek, yakni: 1) Bebas dari gangguan dan penyakit-penyakit kejiwaan; 2) Mampu secara luwes menyesuaikan diri dan menciptakan hubungan antar pribadi yang bermanfaat dan menyenangkan; 3) Mengembangkan potensi-potensi pribadi (bakat, kemampuan, sikap, sifat dan sebagainya) yang baik dan bermanfaat bagi dirinya sendiri dan lingkungannya.

Skala kesehatan mental terdiri dari 33 aitem dengan koefisien validitas aitem bergerak antara 0,19180,5926 dan alphanya 0,8168 .

Religiusitas adalah keadaan yang ada di dalam diri seseorang yang mendorongnya bertingkah laku, bersikap dan bertindak sesuai dengan ajaran agamanya.

Pengukuran religiusitas ini diungkap dengan skala religiusitas yang disusun oleh penulis berdasarkan konsep yang dibuat oleh Glock dan Stark (Robertson, 1998; Ancok dan Nashori, 2000), yang membagi religiusitas menjadi lima aspek, yakni: 1) Ideologi/keyakinan; 2) Ritualistik/praktik; 3) Eksperiensial/pengalaman; 4) Konsekuensial/pengamalan, dan 5) pengetahuan/ilmu. Untuk kepentingan penelitian ini religiusitas diungkap melalui dua skala religiusitas. Dimensi ideologi (keyakinan), ritualistik (praktik) eksperiensial (pengalaman), dan konsekuensial dirangkum dalam satu skala. Pertimbangannya adalah keempat dimensi tersebut sama-sama dimaksudkan untuk mengukur sikap dan perilaku keagamaan seseorang. Skala ini selanjutnya disebut Skala Religiusitas I. Skala religiusitas I terdiri dari 40 aitem dengan koefislen validitas aitem bergerak antara $0,1681-0,6630$ dengan alpha sebesar0.9051.

Religiusitas dimensi pengetahuan diungkap dengan menggunakan satu skala tersendiri. Skala ini selanjutnya dinamakan Skala religiusitas II. Untuk skala religiusitas II, analisis item meliputi taraf kesukaran dan daya diskriminasi, dan uji keandalan. Dengan memperhatikan taraf kesukaran dan daya diskriminasi item ditentukan validitas butirnya. Pengujian dilakukan dengan menggunakan program Microcat (tm) Testing System atau iteman (1988). Dari 20 aitem yang diujicobakan, sebanya 19 aitem dinyatakan valid berdasarkan taraf kesukaran aiterı dan daya diskriminasinya.

Taraf kesukaran menghasilkan koefisien taraf kesukaran item yang bergerak antara 0,330 sampai 0,882 , dengan daya diskriminasi yang bergerak antara 0,44 sampai 0,787 . Koefisien keandalannya adalah 0,762 .

Religiusitas itu multi dimensi, maka pengolahan datanya dilakukan dengan merubah skor masing-miasing dimensi menjadi skor terstandar (skor T). Selanjutnya dicari rata-rata dari kelima dimensi tersebut sebagai skor komposit religiusitas.

Kebermaknaan hidup adalah kualitas penghayatan individu terhadap keberadaan dirinya, yang memuat hal-hal yang dianggap penting, dirasakan berharga, diyakini sebagai sesuatu yang dianggap benar dan dapat memberikan arti khusus. yang menyebabkan hidup berarti dan berharga bagi diri sendiri dan sesama serta menimbulkan kebahagiaan.

Pengukuran kebermaknaan hidup dilakukan dengan menggunakan skala kebermaknaan hidup yang merupakan pengembangan dari skala Pupose in Life (PIL) yang dibuat oleh Crumbaugh dan Maholikh tahun 1984 yang disusun berdasarkan ciri-ciri kebermaknaan hidup. yakni: 1) Tujuan hidup; 2) Kepuasan hidup; 3) Kebebasan memilih; 4) Gairah hidup, dan; 5) Tanggung jawab (Koeswara, 1992).

Skala kebermaknaan hid up terdiri dari 40 aitem dengan koefisien validitas aitem bergerak antara $0,1626-0,5457$ dengan 
aipha 0,8538 .

Metode analisis data yang digunakan dalam penelitian ini adalah teknik statistik analisis regresi ganda dan regresi sederhana. Teknik analis/s regresi ganda digunakan untuk mengukur hubungan religiusitas dan kebermaknaan hidup secara bersama-sama dengan kesehatan mental, sedangkan teknik analisis regresi sedemana dimaksudkan untuk mengetahui ada tidaknya hubungan antara religiusitas dengan kesehatan mental dan untuk mengetahui ada tidaknya hubungan antara kebermaknaan hidup dengan kesehatan menta!.

\section{Hasil Penelitian}

Setelah dilakukan analisis regresi ganda dan regresi sederhana, penelitian Ini menghasilkan temuan-temuan sebagai berikut:

Pertama, hasil analisis data mengenal hubungan antara religiusitas dan kebermaknaan hidup secara bersama-sama dengan kesehatan mental menunjukkan koefisien korelasi $F=82,801$ dengan $p<0,01$. Hal Ini menunjukkan, bahwa ada korelasi positif yang signlfikan antara religiusitas dan kebermaknaan hidup dengan kesehatan mental mahaslswa. Dengan demikian, hipotesis penelitian yang berbunyi ada korelasi positif yang signifikan antara religilusitas dan kebermaknaan hidup dengan kesehatan mental diterima. Hal tersebut berarti semakin tinggi religlusitas dan kebermaknaan hidup mahasiswa, maka semakin tinggi kesehatan mentalnya, sebaliknya semakin rendah religiusitas dan kebermaknaan hidup maka semakin rendah kesehatan mentalnya.

Ditemukan koefisien determinan $\left(r^{2}\right)$ sebesar 0,572 yang berarti bahwa sekitar $57,2 \%$ sumbangan relfglusitas dan kebermaknaan hidup terhadap variabel kesehatan mental, sedangkan sisanya sebesar 42,8 dijelaskan oleh prediktor lain dan kesalahan-kesalahan laln (eror sampling dan non sampling).

Kodua, hasil analisis data mengenai hubungan antara religiusitas dan kesehatan menta! menunjukkan koefisien korelas $\mathbf{F}=$ 67,137 dengan $p<0,01$. Hal ini menunjukkan, bahwa ada korelasi positif yang signifikan antara religiusitas dan kesehatan mental mahasiswa. Dengan demikian, semakin tinggi religiusitas, maka semakin tinggi kesehatan mental mahasiswa, sebaliknya semakin rendah religiusitas maka semakin rendah kesehatan mentalnya.

Ditemukan pula koefisien determinan (r) sebesar0,349 yang berarti bahwa sekltar $34,9 \%$ sumbangan religiusitas terhadap variabel kesehatan mental, sedangkan sisanya sebesar 65,1 dijelaskan oleh prediktor lain dan kesalahan-kesalahan lain (eror sampling dan non samuling).

Kotiga, hasll analisis data mengenai hubungan antara kebermaknaan hldup dengan kesehatan mental menunjukkan koefisien korelasi $F=116,439$ dengan $p<$ 0,01 . Hal inl menunjukkan, bahwa ada korelasi posttif yang signifikan antara kebermaknaan hidup dengan kesehatan mental. Dengan demikian, semakin tinggi kebermaknaan hidup, maka semakin tinggl kesehatan mental mahasiswa, sebaliknya semakin rendah kebermaknaan hidup maka semakin rendah kesehatan mentalnya.

Ditemukan juga koefisien determinan (r) sebesar 0,482 yang berarti bahwa sekitar $48,2 \%$ sumbangan kebermaknaan hidup terhadap varlabel kesehatan mental, sedangkan sisanya sebesar 51,8 dijelaskan oleh prediktor laln dan kesalahan-kesalahan laln (eror sampling dan non sampling).

\section{Pembahasan}

Melalui analisis data diperoleh suatu kesimpulan bahwa ada korelasi positif yang slgnifikan antara religiusitas dan kebermaknaan hidup dengan kesehatan mental pada mahasiswa Fakultas Dakwah IAN Walisongo.

Adanya korelasi yang signifikan antara religiusitas dengan kesehatan mental, sejalan dengan pendapat Surya (Akhmad, 2005), yang menyatakan bahwa kesehatan mental ditentukan oleh beberapa kondisi yang mempengaruhinya, salah satunya 
adalah kondisi keberagamaan seseorang. Sejalan dengan pendapat tersebut, Daradjat (1993) menyatakan bahwa agama dengan ketentuan dan hukum-hukumnya telah dapat membendung terjadinya gangguan kejwaan, yaitu dengan dihindarkannya segala kemungkinan sikap, perasaan, dan kelakuan yang membawa pada kegelisahan.

Salah saku aspek dari ajaran Islam adalah aqidah/keimanan, yakni segala hal yang wajtb diyakini oleh manusia dan yang tak boleh dibenarkan apalagi diyakini keshahihannya (Mahmud, 1994). Seseorang yang keimanannya telah menguasainya, walau apapun yang terjadi tidak akan mengganggu atau mempengaruhinya. la yakin bahwa keimanan itu akan membawanya kepada ketenteraman dan kelegaan batin, karena ada tempat mengeluh dan mengungkapkan segala rasa hati. Dengan kepercayaan akan adanya Tuhan, manusia akan tertolong dalam melepaskan diri dari ikatan benda dan segala sesuatu yang bersifat material, dan akan meringankan segala penderitaan batin yang terjadi. Kepercayaan kepada Allah, merupakan unsur terpenting dalam hidup manusia (Daradjat, 2001). Tanpa kepercayaan pada Tuhan, tidak mungkin orang dapat merasakan ketenangan jwa dan kebahagian dalam hidup. Dengan kata lain kepercayaan kepada Tuhan adalah kebutuhan jwa manusia yang paling pokok, yang dapat menolong orang dalam memenuhi kekosongan jiwanya.

Ajaran Islam selain mengajarkan aspek keimanan sebagaimana diuraikan di atas, juga mengajarkan aspek ibadah. Aspek ibadah meliputi masalah ta',abud kepada Allah dengan segala apa yang telah diwajibkan-Nya kepada kaum muslimin seperti dua kalimah syahadat, shalat, puasa zakat, haj bag yang mampu, dzikir dan segala hal yang disyariatkan Allah (Mahmud, 1994) lbadah-ibadah yang diajarkan dalam Islam tersebut akan berpengaruh positif tehadap kesehatan mental asal dilakukan sesuai dengan pedoman yang disampaikan langsung oleh Allah dengan wahyu-wahyuNya kepada Nabi Muhammad sebagai utusan-Nya, serta mengindahkan perintah dan larangan-Nya.

Salah satu contoh sebuah bentuk ibadah yang paling mudah dan sederhana, tetapi memilikl pangaruh yang sangat positif terhadap kesehatan mental adalah dzikir (menyebut-nyebut nama Allah). Dalam Surat Al-Baqarah ayat 152 Alah SWT berfirman, yang artinya:

Karena ilu, ingatlah (dzikirah) engkau kepada-Ku niscaya Aku ingat (dzikir) pula kepadamu, dan bersyukuriah kepada-Ku dan janganlah kamu mengingkari (nikmat)-Ku.

Bastaman (1995) menyatakan bahwa ayat tersebut menunjukkan bahwa Allah SWT akan membalas dzikir seseorang dengan dzikir-Nya sebagai anugrah. Betapa dahsyatnya karunia llahl ini: Allah SWT mengirimkan Nama-Nya sendiri kepada si pedzikir! Pasti akan dibawa dengan segala keagungannya oleh milyaran malaikat yang suci dan perkasa untuk diturunkan ke dalam ruhani si pedzikir. Bila hal iu terjadi pasti pula segala sifat angkara murka yang bersumber dari nafsu-nafsu pribadi dan syaithaniah akan sima digantikan oleh sifat-sifat lembut, suci, dan perkasa yang akan terperangai sebagai sifat-sifat pribadi seorang mukmin sejati, yang senantiasa secara nyata mendapat bimbingan dan petunjuk-Nya. Lebih lanjut Bastaman (1995) menyatakan bahwa kalau dzikrullah sudah sedemikian dahsyat pengaruhnya terhadap kematangan pribadi dan kesehatan mental, apalagi hasil dari shalat yang terkenal sebagal tjang agama, merupakan milrajnya kaum beriman, dan dapat mencegah perbuatan keji dan munkar!.

Sejalan dengan pendapat d atas, Daradjat (1993) berpendapat bahwa sembahyang, doa-doa, dan permohonan ampunan kepada Allah, dan ibadah-ibadah yang lain, merupakan cara-cara pelegaan batin yang akan mengembalikan ketenangan dan ketenteraman jwa kepada orang yang melakukannya. Semakin dekat seseorang kepada Tuhan, dan semakin banyak ibadahnya, maka akan semakin tenteramlah jlwanya serta semakin mampu la 
menghadapi kekecewaan dan kesukarankesukaran dalam hidup, demikian pula sebaliknya, semakin jauh orang thu dart agama akan semakin susahlah baginya untuk mencari ketenteraman batin. Dengan demikian dapat diperoleh pemahaman bahwa agama merupakan faktor penting yang dapat membimbing seseorang dalam mendapatkan kesehatan mental.

Selaln dimensi akidah dan ibadah, ajaran Islam juga mengandung aspek muamalah, of mana aspek ini tidak dapat dipisahkan dengan dua aspek sebelumnya (aqidah dan Ibadah) karena ketiganya saling berkaltan. Aspek muamalah mencakup segala bentuk sifat yang diupayakan (shifah kasbiyah) oleh seorang muslim, seperti akhlak individual, sikap kepada Allah, diri dan lainnya(Mahmud, 1994).

Ajaran Islam sangatmenekankanakan pentingnya akhlak yang baik. Banyak ayatAJQur'an yang mengajarkan tentang kebaikan, salah satunya adalah firman Allah, yang artinya:

Dan belanjakanlah (harta bendamu) of jalan Allah, dan janganlah kamu menjatuhkan dirinu sendiri ke dalam kebinasaan, dan berbuat baiklah, karena sesung guhnya Allah menyukai orang-orang yang berbuat baik (QS. Al-Baqarah (10): 195).

Selain ayat di atas, Rasulullah juga banyak mengajarkan pada umatnya untuk selalu berbuat baik, bahkan selalu meningkatkan amal kebaikannya. Salah satu hadits Rasulullah sebagaimana tersebut d bawahini:

Barang siapa hari kininya lebih baik dari harl kemarinnya, maka dia tergolong orang yang beruntung. Barang slapa hari kininya sama dengan hari kemarinnya, maka dia tergolong orang yang tertipu. Barangsiapa hari kininya lebih buruk dari hari kemarinnya, maka dia tergolong orang yang teriaknat ( $\mathrm{Al}$ hadits).
Bila direnungkan ayat dan hadits di atas maka jelas terlihat bahwa Islam mengajarkan pada umatnya untuk meraih hidup yang baik dan selamat, serta meraih kondisi mental yang sehat.

Jadi menurut hemat penulis, penghayatan dan pengamalan agama merupakan faktor penting yang dapat mempengaruhi kesehatan mental. Karena dengan menghayati dan mengamalkan agama dengan sungguh-sungguh, maka keimanan dan ketakwaan akan diraih.

Melalui beriman dan takwa, manusla mampu bersikap tenang dan sabar dalam menghadapi problema hidup dan mampu berpikir secara seimbang serta kondisi kejwaannya penuh dengan ketenteraman dan kedamaian karena selalu mengingat Allah. Maka dart itu, orang yang menyikapi penderitaan yang dialaminya dengan sabar dan menyadari bahwa di balik penderitaan terdapat hikmah, dapat digolongkan sebagai orang yang sehat mentalnya. Sebaliknya, orang yang menyikapi penderitaannya dengan keluhan dan kekecewaan merupakan orang yang mengalami gangguan mental.

Hasll analisis statistik juga menunjukkan bahwa ada korelasi positif yang signifikan antara kebermaknaan hidup dengan kesehatan mental. Hal ini sejalan dengan pendapat Ancok (2003) yang menyatakan bahwa kehldupan yang sehat adalah kehidupan yang penuh makna. Hanya dengan makna yang baik orang akan menjadi insan yang berguna tidak hanya untuk diri sendiri tetapi juga untuk orang lain, Kerusakan moral dan gangguan jiwa adalah karena orang tidak memillikl makna hidup yang baik. Hasil penelittan ini juga sejalan dengan Setiyartomo (2004) yang menyatakan bahwa kebermaknaan hidup sangat penting bagi terwujudnya kesehatan mental.

Keterkaitan antara kebermaknaan hidup dan kesehatan mental dapat ditelusuri dari sumber utama kebermaknaan hidup dan kesehatan mental itu sendiri. Keduanya bersumber bagaimana cara dan sikap seseorang dalam menghadapi persoalan hidup. Daradjat (2001) menyatakan bahwa 
sesungguhnya ketenangan hidup, ketenteraman jwa atau kebahagiaan batin, tidak banyak tergantung kepada faktor-faktor luar seperti keadaan sosial, ekonomi, politik, adat kebiasaan, dan sebagainya; akan tetapi lebih tergantung kepada cara dan sikap menghadapi faktor-faktor tersebut.

Keterkaitan antara kebermaknaan hidup dengan kesehatan mental dapat dipahaml juga dari ajaran Logoterapi. Logoterapi mengajarkan bahwa manusia harus dipandang sebagai kesatuan ragajwa-rohani yang tak terpisahkan. Seorang psikoterapis tidak mungkin dapat memahami dan melakukan terapl secara baik apabila mengabaikan dimensi rohani yang justru merupakan salah satu sumber kekuatan dan kesehatan manusla. Logoterapi juga memusatkan perhatian pada kualitaskualitas insani, seperti hasrat untuk hidup bermakna, hati nurani, kreativitas, dan tanggung jawab. Frankl memanfaatkan dan mengaplikasikan kualitas-kualitas itu dalam terapi dan pengembangan kesehatan mental, termasuk penyembuhan mental yang sakit (Bastaman, 1996).

\section{Penutup}

\section{Simpulan}

Simpulan penelitian ini adalah terdapat korelasi positif yang signifikan antara religiusitas dan kebermaknaan hid up dengan kesehatan mental. Semakin tinggl religiusitas dan kebermaknaan hidup maka semakin tinggi kesehałan mental mahasiswa Fakultas Dakwah IAIN Walisongo, sebaliknya semakin rendah religiusitas dan kebermaknaan hidup maka semakin rendah kesehatan mentainya. Religiusitas dan kebermaknaan hidup secara bersama-sama mampu mempengaruhi variabel terlkat (kesehatan mental) sebesar $57,2 \%$.

\section{Saran}

Berdasarkan penelitian ini dapat diketahul bahwa religiusitas dan kebermaknaan hidup seseorang mempunyai peranan yang penting dalam mewujudkan kesehatan mental.

Subjek penelitian diharapkan memiliki kesadaran akan pentingnya kesehatan mental. Kerena sedemikian pentingnya, maka semua pihak, termasuk mereka, perlu memupuk kesehatan mental itu. Cara yang dapat ditempuh adalah meningkatkan religiusitas dan kebemaknaan hidup. Untuk meningkatkan religius/tas dan kebemaknaan hidup, di samping memanfaatkan perkuliahan agama pada khususnya dan perkuliahan pada umumnya secara optimal, para mahasiswa juga pertu memanfaatkan aktivitas ekstra kurikuler yang terdapat o kampusnya. Aktivitas mahaslwa di organisasi kemahasiswaan, keagamaan, kepemudaan pertu dioptimalkan.

\section{Daftar Pustaka}

Akhmad, P. 2005. Terapl Ruqyah Sebagal Sarana Mengobati Orang yang Tidak Sehat Mental. Jurnal Psikologi Islami, 1, 87-99.

Ancok, D. dan Suroso, F. N. 2000. Psikologi Islam; Solusi Islam atas Problemproblem Ps/kologl. Yogyakarta: Pustaka Pelajar.

Ancok, D. 2003. Pengantar. Dalam Victor E. Frank, Logoterapi; Terapi Psikologi Melalui Pemahaman Eksistensi. Penterjemah M. Murtadlo. Yogyakarta: Kreasi Wacana.

Anggriany, N. 2006. Motif Sosial dan Kebermaknaan Hidup Remaja Pagaralam. Jumal Psikologika, 21. 51-63.

Bastaman, H. D. 1995. Integrasi Psikologi dengan Isiam; Monuju Psikologl Islami. Yogyakarta: Pustaka Pelajar dan Yayasan insan Kamil.

Bastaman, H. D. 1996. Moraih Hidup Bermakna, Kisah Pribadi dengan Pengalaman Tragis. Jakarta: Paramadina.

Bergin,A. E Masters, K S dan Richard, P. S. 1997. Religiousness and Mental 
Helth Reconcidered: A Study of an Instrically Religious Sample. Jumal of Counseling Psichology, 34, 197204.

Budiharjo, P. 1997. Mengenal Teori Kepribadian Mutakhir. Yogyakarta: Kanisius.

Daradjat, Z 1993. Peranan Agama dalam Kesehatan Mental. Jakarta: Haji Masagung.

Daradjat, Z. 2001. Kesehatan Mental. Jakarta: PT GunungAgung.

Franki, V. E 2003. Logoterapi; Terapi Psikologi Melalui Pemahaman Eksistensi. Penerjemah M. Murtadlo. Yogyakarta: Kreasi Wacana.

Jalaluddin. 2000. Psikologi Agama. Jakarta: PT. RajaGrafindo Persada.

Kartono, $\mathrm{K}$ dan Andari. 1989. Hygiene Mental dan Kesehatan Mental dalam Islam. Bandung: MandarMaju.
Koeswara, E. 1992. Logoterapi, Psikoterapi Victor Frankl. Yogyakarta: Kanisius.

Mahmud, A.A.H. 1994. Fiqh Da'wah Fardiyah. Jakarta: Robbani Press.

Robertson, R (ed) 1988. Agama dalam Analisa dan Interpretasi Sosiologis. Jakarta: Rajawali.

Setlyartomo, P. W. 2004. Succesfull Aging Ditinjau dari Kebermaknaan Hidup dan Orientasi Religitus pada Lansia. Tesis. Yogyakarta: Program Stud: Psikologi Universitas Gadjah Mada.

Widjanarko, M. 1997. Hubungan Sikap Religius dengan Rasa Bersalah pada Remaja Akhir yang Beragama Islam. Jumal Psikologika, 3, 47-50. 